\title{
The Moderating Effect of Innovation on the Relationship between Enterprise Risk Management Strategies and Performance of Christian Hospitality Sectorin Kenya - An Empirical Overview
}

\author{
Midikira Churchill Kibisu ${ }^{1} \&$ Zachary B. Awino ${ }^{1}$ \\ ${ }^{1}$ School of Business, University of Nairobi, Kenya \\ Correspondence: Zachary B. Awino, School of Business, University of Nairobi, Kenya. E-mail: \\ zb.awino@gmail.com \\ Received: September 27, 2017 \\ Accepted: October 28, 2017 \\ Online Published: November 20, 2017 \\ doi:10.5539/ijbm.v12n12p212 \\ URL: https://doi.org/10.5539/ijbm.v12n12p212
}

\begin{abstract}
This study intended to determine the moderating effect of Innovation on the relationship between Enterprise risk Management Strategies (ERMS) and performance. The context of the study was the Christian-based hospitality businesses in Kenya. Indicators of performance were both financial and non-financial and data was sought both from primary and secondary sources. The Null hypothesis was formulated for testing the relationship using a significance $\mathrm{p}$-value of $\mathrm{p}<0.05$. The study adopted a positivistic philosophy using descriptive cross-sectional survey design on a population of 76 Christian-based hospitality businesses in Kenya which are unlisted. A $65.8 \%$ response rate was achieved. This concludes that innovations adopted by Christian Hospitality Sector in Kenya have a significant moderating effect on the relationship between enterprise risk management strategies and performance. The results implies that for the Christian-Based Hospitality Businesses in Kenya to improve performance effective enterprise risk management strategies must combine with effective innovative practices in order to perform well.
\end{abstract}

Keywords: enterprise risk management strategies, innovation, performance and hospitality business

\section{Introduction}

Risk Management has grown over the years to include not only financial investments decisions and insurance, but general pure or insurable and uninsurable risks. The function of Enterprise Risk Management (ERM) is to protect, conserve and maximize the owner's wealth or value addition (Kraus \& Lehner, 2012). In this regard, management is able to successfully manage risks and exploit all favourable opportunities and prospects to enhance value for the organization. Enterprise risk management strategies (ERMS) should therefore align risk appetite and strategy, which can easily enhance responses to decisions that can reduce any operational surprises and losses, while at the same time being able to identify and managing across the board enterprise risks, and being able to effectively improve the deployment of capital (COSO, 2011). Strategy has diverse definitions given by various authorities. This is because strategy tends to be multidisciplinary and multidimensional and it is expected to affect the welfare of the organization through achieving stakeholder needs.

Innovation on the other hand has been described as, the act or process of introducing new ideas, devices or methods. From an operational and economic point of view, innovation may be regarded as a means of converting a conception or a new development into a product that is acceptable to buyers who are willing to part with some money in exchange (Frankelius, 2009). Systems dynamics application to ERM process and innovation are interactive. From an organizational context, innovation should lead to new and positive ways of operations leading to efficiency, quality services and products that meet market needs in a competitive manner. The old adage is that the organization is as good as its people (Barret, 2006).

Failure of business can be traced in the weakness in the control environment which requires a linkage between ERMS and innovation as both are expected to create value for the stakeholders and hence good performance that captures development and change over time which are measured using appropriate indicators, financial and non-financial (Carneiro, 2005). Risk Management generally ensures an orderly way of analyzing managerial functions which place an emphasis on responding to the intrinsic ambiguities of managing a multifaceted business and resources. Therefore, risk management strategies and innovation when properly integrated lead to 
improved performance.

Tourism is an industry encompassing many sectors where hospitality is part .On a global scene, hospitality industry comprises international hotels, resorts, quick service restaurant chains and travel, all attached to the tourism industry as an important export for many nations. Faith based businesses have grown significantly and the businesses and activities undertaken are diverse in nature and include real estate, schools, universities and even financial institutions such as banks and insurance. However, apart from schools the most dominant business is the hospitality business. There are 76 (seventy six) identified Christian-based hospitality businesses operating in Kenya today (Registrar of Societies/National Christian Council of Kenya -NCCK, 2015). These carry out hospitality businesses that include hotels, guest houses, apartments, restaurants fitness, touring and conferencing and resorts, among other services, not necessarily for profit but for income generation for the church and other socially related activities according to their mandate. Hospitality enterprises are therefore an integral part of the tourism industry globally where Kenya features significantly and a sector which contributes significantly to economic prosperity.

The focus and scope of these businesses over time must be to achieve a competitive advantage in an environment that is ever changing and be able to configure or align various resources including skills and other competences in order to satisfy stakeholders' needs. This is the focus of any strategy (Johnson, Scholes \& Whittington, 2008). Methods for measuring performance in non-profit organizations differ widely. Qualitative methods tend to be highly organizational specific, meaning issues like improved administrative practices or mission accomplishment or the softer performance such as member satisfaction or reputation within the organization. Quantitative measures like donation increases and programmes funding ratios have also been used to measure performance for these organizations. The cornerstone of Church performance is on mission of people growth that is saving of people's souls which is a by-product of any business the Church engages in. However, other economic performance parameters such as ROA and Revenue per Available Room and even ROE may be used to asses how these organizations perform.

\section{Literature Review}

According to Vaughan (2014), risk is the adversative divergence from the expected results and which is accompanied by a financial loss. He goes on to state that risk management, as a concept, deals with two broad ways of managing risks: risk control and risk financing.

Risk control deals with various mechanisms of risk management. Loss reduction may be achieved by minimization of relationships risks through goodwill trust, behaviuor and societal control. It may also entail minimization of performance risks through competence trust, output and social control. Risk control may be achieved through other strategies such as loss prevention that may include good governance through improved skills, duplication of similar activities at different locations, separation of operations or assets, diversification of activities or investments and risk avoidance of activities that are likely to create losses (Das \& Teng, 2001; Chan, 2013).

Risk financing on the other hand deals with various mechanisms of risk transfer and risk retention which would require internal or external resources to finance the risks. Shifting a risk from self to another party through some insurance agreement is a strategy of minimizing the effects of such a risk on the insured person. In this respect when risk transfer is through insurance, the policyholder does not have to worry of possible loss (Banks, 2004). Other examples of risk transfer strategies include hold-harmless clauses in contracts, surety bonds in construction industry, outsourcing and hedging. Risk management process must involve risk identification, measurement, acceptance based on criteria for risk apatite, implementation of selected tools and monitoring and review governed by an organizational policy that is promulgated by the top management or the Board of Directors (BOD). Such policy must be cascaded downwards for the lower cadre staff to implement under the guidance of some risk officer.

On the other hand Copeland, Weston and Shastri (2005) posit that risk management establishes the growth of regular dividend payments for the stated period as opposed to sheer capital gains. That is for the shareholder to benefit and feel satisfied from a risk management activity, his wealth must be seen to be maximized by the growth in dividend receipts and other benefits. On the other hand, Georges (2013) states that risk management is to do with the restructuring and reduction of organizational risks that leads to maximizing its value. Managers and organizations prefer stability other than volatility because stability provides an environment for utility for various stakeholders.

There are various burdens that increase risk. These include among others: personal managerial shortcomings and interests that impair decision-making; taxes that are nonlinear that tend to reduce the value of organizations; the 
cost of financial distress; market deficiencies; operational weaknesses (Santomero \& Babbel, 1997). Therefore any enterprise risk management strategy must overcome some of these risks and yield some benefit to the stakeholder.

However, enterprise risk management in its totality is an integrated process that goes beyond insurance (Klein, 2013) to include non-insurance mechanisms. Strategy on the other hand involves a set of activities undertaken according to a plan in order to achieve an overall goal. It determines who, when, where and how the plans are to achieve the organizational goals and objectives (Thompson \& Strickland, 2008). Traditional Risk Management (TRM) has been known to be highly disaggregated in managing risk. That is each type of risk is managed by a specific unit in a silo approach. The driving forces behind integrative Enterprise Risk Management (ERM) is the complex nature of the emerging risks such as external factors as globalization of business such as hospitality, consolidation of business, legal and regulatory regimes on corporate governance, technological advancement that may impact better methods of identifying, measuring, analyzing and mitigation of risks. From internal perspective, there is pressure to maximize stakeholders' wealth or value. Therefore, ERMS must in essence in a holistic way reduce the TRM imperfectness or inefficiencies and enhance value addition through capital growth, earnings stabilization and reduction of cost burdens. At the same time ERMS must deal with regulatory requirements that come from government or the relevant industry that are likely to impede sustainable stability. (Liebenberg, 2003).

In its application, ERM is to explain an arrangement of critical and managerial functions that aim at generating a positive reaction to in-built ambiguities in the management of multifaceted and intricate business and its resources. Enterprise risk management strategies (ERMS) help to contribute to the drive of organizational-wide ethos and style in business management that stimulates tactical evaluation of risks in order to avoid accepting undesirable risks that could easily harm an organization (Hoyt \& Liebenberg, 2011). An enterprise-wide approach to risk management enables consideration of potential impact of all types of risks on all processes, activities, stakeholders' products and services. This therefore tends to avoid a silo approach of identifying and managing the diverse risks faced by an organization.

Integrated ERMS provides for incorporation of policy, rules and regulation in order for the organization to control their activities in achieving their goals. It also allows for companies to consistently deliver superior performance while proactively managing risks. This therefore calls for a socially integrated framework that is composed of various skills that can be used to drive the organization and even evaluate the ERM processes (COSO, 2001).

ERMS should also involve organizational restructuring for purposes of achieving efficiency. This can be achieved through an integrated structure, thus turning to strong relationships and actions when organizations are faced with uncertainties which may be work related, financing related structural dynamics, and social capital embedded in social structure, all of which require configuration (McKinley \& Scherer, 2000; Levin \& Murninghan, 2011). Unlike some aspects of ERM integrative strategies, restructuring activities may be a one-time undertaking that is not repeated very often, for example management processes such as divesture, spin-offs, acquisition, stock-repurchase and debt swaps (Gibbs, 2007; Sterman, 2002).

Some of the effective risk management determinants that may be used in support of an integrated approach include among others: internal audit effectiveness, that is the ability of the organization to monitor and pinpoint areas of weaknesses and being able to address these weaknesses; human resource competencies that assures proper understanding of the problems and ability to implement any strategies recommended; regulatory influence support that ensures compliance of not only the legal framework but also professional compliance; top management commitment to policy and to strategy implementation as illustrated in the three lines of defense theory (Nocco \& Stulz, 2011; Gibbs, 2007).

ERMS are therefore useful because investors and managers must select those projects with positive Net Present value (+ve NPV) without much regard to criteria such as the payback period or Internal Rate of Return (IRR) which do not guarantee undertaking projects that maximize shareholders' wealth, a view supported by International Standardization Organization-ISO (2015). However, risks should be signals of financial performance and how organizations manage them. Most investors tend to ignore ERM especially those related to qualitative data and giving more attention to quantitative data that is easily compared between various firms (Agustina, 2016). ERM should not be undertaken from individualistic silo type of risk management, but rather from a comprehensive, strategic and integrated system (Koelling, Neyer, \& Moeslein, 2010; Krause \& Lehner, 2012). This comprehensive approach is the upside of risk (ISO3100, 2015), that is risk can be very pervasive and requires a multiplicity approach in identifying and managing it. ERMStherefore epitomizes tremendous change 
in risk management different from past practices such that it involves all functional areas of management.

Effective ERM and traditional risk management (TRM) promote demonstrated commitment by managers and engagement into performance evaluation and providing incentives for success (McShane, Nair, \& Rustambekov, 2011). It is important to note that enterprise risk management (ERM) strategies help to contribute to an organization wide culture of management which promotes strategic risk taking and prevents illogical risk aversion.

Ideally Integrated Management System (IMS) as one of the features of ERMS, should be the goal of any organization. This is despite the fact that such IMS may not be very easy to actualize due to a multiplicity of systems in one organization. However, such integration makes sense (ISO 9001: 2015). The success of any business must be part and parcel of any management system. It is clear that to achieve this success in all spheres of business operation an integrated management systems must specifically focus on guaranteeing quality, good health, social environment promoting not only safety but also good governance in areas such as human resource governance, financial management among others and any process and documentation must relate to this integration (Vasile \& Ion, 2012). Such integration can be achieved through teams that can achieve efficient management systems (EMS) such as compliance, identification of weaknesses and quick and effective decision making. This brings on board diverse skills and defense mechanisms that can easily deal with exposure to the diverse risks taking into consideration resources available, external influences and various channels of communication that enhance decision making

In summary, any organization that places some premium on managing risk will easily handle or cope with the ever-growing organizational risks and in the process seizing any existing opportunities that enhance growth and profitability (Olavsrud, 2015). Such an organization is likely to be more competitive than if it did not embrace various technique of risk management.

Innovation is a disambiguation that may lead to the application of better solutions that meet new requirement and inarticulate needs which is to be found in various disciplines of management (Frankelius, 2009). Due to its pervasiveness and whose effects are often ambivalent, it leads to opposite direction from the normal depending on the goals of the innovator. Systems dynamics application to ERM process and innovation are therefore interactive. The creator must allow for flexibility in thought and application that can change with changing circumstances. Such innovation when conceptualized must go through a process that allows for visions that are shared by others for easy implementation (Perry-Smith \& Mannucci, 2017). Innovation may also be considered as concept conversion into products and services (Rogers, 2003) while process innovation implies implementation of improved methods that reduce costs (Henry \& Mayle, 2002).

From a broader perspective innovation may involve change of business model which can easily be adaptable to environmental diversities and be able to address stakeholder needs and achieving competitive advantage (Thorburn \& Langdale, 2003).

It should be noted that innovation through data dispensation strategy, are in most cases associated with firm performance while interlinking others to an identified strategy position for instance when the motive is to increase cost effectiveness and effective communication dissemination for decision making (Fairbank, Labianca, Steensma \& Meters, 2006). From empirical studies made a positive relation has been shown to exist linking innovation and some aspects of ERM. For example: Hurley and Hult (1998) in their study established that high planes of innovation in the firms' cultural values are linked to a high extent of adaptability.

The study also revealed that greater levels in innovation are also linked to organizational values which underscore knowledge acquisition progress and all- inclusive and integrated decision-making which is an essential risk management strategy. Gebert and Boemers (2003) in their study showed that more decentralization of power and participative leadership provides empowerment and thus greater situation control of specific risks. Decentralization may be looked at as being both ERMS and an innovative way of governance.

Market orientation as a strategy, may determine the nature of innovation to be adopted. Verhees and Muelenberg (2004) in their study exploring the joint effect of market orientation and innovation and firm performance of 152 rose growers in Spain, revealed that innovation pervades all variables and had positive impact on market orientation. The study also established that customer market knowledge influences innovation positively or negatively depending on the weakness or strength of the innovation. Similarly, Tsai (2001) in the study of 24 business units in a petrochemical company and 36 business units in food manufacturing company showed that interaction between absorptive capability and networking position has a significantly positive impact on business innovation and performance. These studies show that innovation is critical to firm performance as supported by the study by Laursen and Salter (2006) of large-scale companies in UK that showed that a search strategy to 
innovation has a curvilinear relationship with performance.

However, short of a synchronous integration that will moderate all the risks and allows for adaptation, compromise and belief, enhancing management of the prevailing conditions does not necessarily lead to enhanced innovation but to reduction. This observation illustrates the underlying curved (curvilinear) relationship between managing prevalent environments and innovation and hence exposes existence of risks. Camison and Villar-Lopez (2014) in their study of Spanish Industrial businesses established that business innovation supports advances in technologically oriented innovation and technology in production and other systems leads to greater and improved performance. While Hurley and Hult (1998) established that innovation has an impact on capacity adaptation leading to greater performance. In case studies of 30 Australian small businesses (Thorburn \& Langdale, 2003), established that incremental innovation was mainly directed towards high quality and customized products and services and niche markets, and listening to customer and their input was equally important.

In his study of Organizational Innovation using a Meta-Analysis methodology of the effects of the determinants and moderators of innovation, Damanpour (1991) sought to test three major areas. First to test the hypothesized relationships among organizational factors and evaluate the validity of the assumed instability with innovation. This instability was found to be insignificant from the study. Secondly, he explored the dimensions that have an effective moderation impact on the relationship between innovation and its determinants The study showed that types of innovation represented by administrative innovation and technical innovation, and stage of innovation represented by initiation stage and implementation stage did not have significant effect on the moderation, while the scope of the innovation and type of organization had a significant moderating effect on the relationship.. Thirdly he tested some of the existing theories of innovation and found connection with its adaptability in the firms. The study concluded that the type of organization and the scope of innovation are key moderators in the relationship between determinants and innovation.

Small businesses however, face inherent problems especially in the adoption of innovation. These include mostly financing inabilities, lack of competent staff, marketing overseas and relying heavily on the founder of the business. These problems make most firms to struggle with growth and their inability to understand and codify knowledge. This confirms the findings by Damanpour on the scope and type of organization as innovation moderators.

Kaur, Naqshbandi and Jayasigham (2014) posit that there are drivers and inhibitors of open innovation among the Small and Medium Size Enterprises (SME's). One of the crucial drivers of innovation is meeting customer needs, while inhibitors include staff resistance based on whether the innovation is created within the organization or from another source. At the same time in their study (Naqshbandi \& Singh, 2014) innovation effectiveness will depend on the managerial ties with external organizations such as universities for in-bound innovation in support of it while managerial ties with other firms does not have an effect. They also posit that managerial ties are not significant in out-bound innovation meaning that sharing of innovation between firms may not be easy.

Christian-based hospitality businesses definitely operate in a competitive environment either between themselves or with other market oriented local and international hospitality businesses. In such a competitive environment innovation such as new business model or product innovation can affect the non-innovative competitor. To such a non-innovative competitor these would be regarded as disruptive innovation. Such disruptive innovation succeeds for the innovative competitor because they utilize their ability to consistently continue to develop and improve their businesses through leveraging innovation as they reach out to the old and new clients. This approach may not necessarily call for competitive pricing, but rather to a continued market penetration (Wessel $\&$ Christenson, 2012). For the non-innovative competitor, the only redress against disruptive innovation is to maximize on their strengths. The Christian hospitality businesses because of their resource limitation could adopt this strategy.

All these studies reveal that an integrated approach to risk management through innovation is critical and hence the three lines of defense theory comes in handy in dealing with the presence of risks at different levels of the organization. His should be supported by the available resources available.

Orlando (2000) argues that for human capital to subscribe to sustainable competitive advantage, it must create value. ERMS therefore denotes substantial development and improvement hitherto experienced through various approaches of managing business risks whether systemic, environmental, legal compliance and services among others. Whereas Christian-based organizations' main preoccupation is soul redemption and social programmes various intervention mechanisms including innovation should be undertaken in order to fulfill stakeholder expectations. Performance is an organizational achievement or success which may be measured in various 
financial and non-financial parameters (Kaplan \& Norton, 2008) which must result in innovative output clearly visible in performance

Performance is a dependent variable that is regularly used in research. Firms go into commerce to prosper. The level of prosperity or success is measured in terms of business performance (Warren, 2008). Drury (2000) argues that there are two approaches of measuring firm performance: the traditional accounting or quantitative performance measures and contemporary and qualitative firm performance approaches. Drury (2000); Kaplan and Norton (2008); Carton and Hoffer (2006) among others argue that such accounting measures comprise financial reports from which information regarding scales of revenue, cash flows, profitability, and other financial ratios such as return on assets, return on equity, return on investment (ROA, ROE, ROI) among other liquidity ratios may be obtained to reflect firms' performance. In the hospitality industry, performance may be based on: Average daily rate (ADR), Revenue per available room (RevPar) and Occupancy rate (OR), O'Connor and Murphy (2004). Critical issues arise in the use of this variable such as selection of indicators based on convenience and little on consideration of its dimensionality (Combs, Crook \& Shook, 2005; Crook, Ketchen, Combs \& Todd, 2008).

The for-profit organizations conventionally deal with exchange relationship that is trading money for products and/or services. They therefore deal with two resource markets: Resource allocation market to which they provide services, and the resource attraction market from which they receive resources. These markets overlap in the faith based sector because in most cases the services are provided to members through some form of resource allocation and it is the same members from whom resources are attracted (White \& Simas. 2008) and the benefits are to members and society as a whole unlike for-profit businesses where the shareholder is key.

From a conceptual point of view, most studies have not delved into enterprise risk management strategies and its relationship with innovation and their impact on Christian-based organizations' performance in Kenya specifically. However,in using logistic regression framework, Liebenberg and Hoyt (2003) in their study of determinants of ERM implementation concluded that businesses whose capital is highly leveraged prefer a chief risk officer (CRO) in their employment. This is an innovative way of managing risks that is likely to reduce the cost burdens that come with exposure to risk and hence impacting performance positively. Also Ping and Muthuveloo (2015) in their study of public listed Malaysian companies established that the companies that implemented ERM had a positive and significant effect on performance and also that BOD monitoring, size and firm technological complexity significantly affected the relationship between ERM implementation and firm performance. Therefore ERMS combined with appropriate innovative procedures are likely to impact Christian hospitality business significantly. Figure 1 shows the conceptual framework of this relationship.

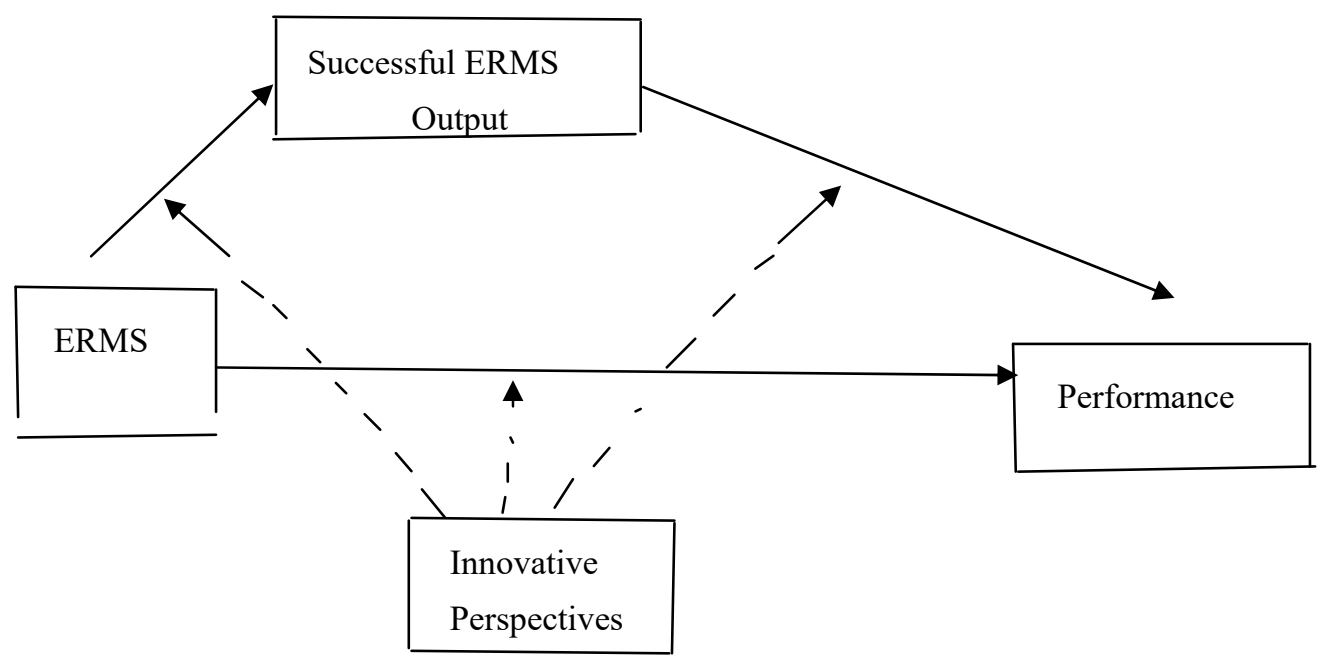

Figure 1. Conceptual Framework

Note: The solid lines represents the direct and indirect pathways, while dotted lines represent moderation. It is assumed that not all ERMS may be successful.

The objective of this study was to determine the effect of innovation on the relationship between ERMS and performance of Christian Hospitality Sector in Kenya. It is therefore hypothesized that there is a significant 
moderating effect by innovation on the relationship between Enterprise Risk Management Strategies and Performance of Christian Hospitality Sector in Kenya (Ha)

\section{Methods}

A descriptive cross-sectional survey was adopted in this study with a population of 76 Christian-Based hospitality businesses in Kenya according to Registrar of Societies Government of Kenya and National Council of Churches in Kenya 2015. Primary data was collected via questionnaires from managers and secondary data, especially financials where there were not given, was collected from returns made to the registrar of societies. The financial data included revenues, total assets for calculating return on assets (ROA), room charges, room occupancy for calculating Average Revenue per Available Room.

The variables in this study were enterprise risk management strategies as independent variable, innovation as a moderating variable and performance as the dependent variable. Reliability test was determined using Chronbach's Alpha with an acceptable minimum value of 0.7 while Validity Tests were carried out using Exploratory Factor Analysis (EFA) and a sampling adequacy using Kaiser-Meyer-Olkin (KMO) approach. Data on enterprise risk management strategies, innovation and performance was analyzed using descriptive statistics of mean, standard deviation, coefficient of variation and percentages. The non-numeric analysis used transcription method. Regression analysis was used to establish relationship between the study variables. The study variables included ERMS as independent variable, innovation as the moderating variable and performance as the dependent variable. The hypothesis was "Innovation has a significant moderating effect on the relationship between ERMS and performance of Christian-based hospitality businesses in Kenya".

The linear regression model developed for this study is as follows:

$$
\text { Ha: } Y=\beta_{0}+\beta_{2-1} X_{2-1}+\beta_{2-2} X_{2-2}+\beta_{2-3}(E R M S * I N N V)+\varepsilon_{2}
$$

Where, $\mathrm{Y}$ is composite values of performance, $\beta_{0}$ is a constant or intercept, $\beta_{2-1}, \beta_{2-2}$ regression coefficients for Ho, $\mathrm{X}_{2-1}$ are dimensions of ERMS and $\mathrm{X}_{2-2}$ are innovation variables and $\varepsilon_{2}$ error term.

The interpretation of this analytic model was If: $\Delta$ " $\mathrm{R}^{2}$ coefficient is significant then the interaction terms " $\beta_{2-3}$ should be significant. The p-value or change in:" $R^{2}$ should also be significant $(<0.05)$

\section{Results}

Data was collected from 50 out of 76 Christian-Based Hospitality Businesses in Kenya representing 65.8\% response. The regression analysis for the study variables is given Table 1 with performance as the dependent variable and ERMS and innovation as predictors.

Table 1. Model Summary, ANNOVA and Coefficients for Ha

\begin{tabular}{|c|c|c|c|c|c|c|c|c|c|c|}
\hline \multicolumn{11}{|c|}{ Model Summary } \\
\hline \multirow[t]{3}{*}{ Model } & \multirow[t]{3}{*}{$\mathrm{R}$} & \multirow[t]{3}{*}{ R Square } & \multirow{3}{*}{$\begin{array}{l}\text { Adjusted } \\
\text { Square }\end{array}$} & \multicolumn{3}{|c|}{ RStd. Error ofChange Statistics } & \multicolumn{4}{|r|}{ Durbin-Watson } \\
\hline & & & & the Estimate & $\mathrm{R} \quad \mathrm{s}$ & SquareF Change & df1 & df2 & Sig. & $\bar{F}$ \\
\hline & & & & \multicolumn{3}{|c|}{ Change } & \multicolumn{4}{|c|}{ Change } \\
\hline 1 & $0.367^{\mathrm{a}}$ & 0.135 & 0.084 & 3.497 & 0.135 & 2.654 & 1 & 17 & 0.122 & \\
\hline 2 & $0.619^{\mathrm{b}}$ & 0.383 & 0.306 & 3.045 & 0.248 & 6.426 & 1 & 16 & 0.022 & \\
\hline 3 & $0.628^{\mathrm{c}}$ & 0.394 & 0.273 & 3.116 & 0.011 & 0.280 & 1 & 15 & 0.604 & 2.507 \\
\hline \multicolumn{11}{|c|}{ a. Predictors: (Constant), Enterprise risk management } \\
\hline \multicolumn{11}{|c|}{ b. Predictors: (Constant), Enterprise risk management, Innovation } \\
\hline \multirow{2}{*}{\multicolumn{11}{|c|}{$\begin{array}{l}\text { c. Predictors: (Constant), Enterprise risk management, Innovation, Interaction term between enterprise risk management and Innovation } \\
\text { d. Dependent Variable: Organizational performance }\end{array}$}} \\
\hline & & & & & & & & & & \\
\hline \multicolumn{11}{|c|}{ ANOVA } \\
\hline \multirow[t]{2}{*}{ Model } & \multicolumn{3}{|r|}{ Sum of Squares } & $\mathrm{df}$ & \multicolumn{2}{|c|}{ Mean Square } & $\mathrm{F}$ & & \\
\hline & \multicolumn{2}{|c|}{ Regression } & 32.460 & 1 & & 2.460 & 2.654 & & \multicolumn{2}{|l|}{$0.122^{b}$} \\
\hline \multirow[t]{3}{*}{1} & \multicolumn{2}{|l|}{ Residual } & 207.887 & 17 & \multicolumn{2}{|c|}{12.229} & & & & \\
\hline & \multicolumn{2}{|l|}{ Total } & 240.347 & 18 & & & & & & \\
\hline & \multicolumn{2}{|c|}{ Regression } & 92.029 & 2 & \multicolumn{2}{|c|}{46.015} & 4.964 & & \multicolumn{2}{|l|}{$0.021^{\mathrm{c}}$} \\
\hline \multirow[t]{2}{*}{2} & \multicolumn{2}{|c|}{ Residual } & 148.318 & 16 & \multicolumn{2}{|c|}{9.270} & & & & \\
\hline & \multicolumn{2}{|l|}{ Total } & 240.347 & 18 & & & & & & \\
\hline \multirow{2}{*}{3} & \multicolumn{2}{|c|}{ Regression } & 94.747 & 3 & & 1.582 & 3.254 & & $0.050^{\mathrm{d}}$ & \\
\hline & Residua & & 145.600 & 15 & & 707 & & & & \\
\hline
\end{tabular}




\begin{tabular}{|c|c|c|c|c|c|c|c|c|}
\hline \multicolumn{9}{|c|}{$\begin{array}{lll}\text { Total } & 240.347 & 18\end{array}$} \\
\hline \multicolumn{9}{|c|}{ a. Dependent Variable: Organizational performance } \\
\hline \multicolumn{9}{|c|}{ b. Predictors: (Constant), Enterprise risk management } \\
\hline \multicolumn{9}{|c|}{ c. Predictors: (Constant), Enterprise risk management, Innovation } \\
\hline \multicolumn{9}{|c|}{ d. Predictors: (Constant), Enterprise risk management, Innovation, Interaction term between enterprise risk management and Innovation } \\
\hline \multicolumn{9}{|c|}{ Coefficients $^{\mathrm{a}}$} \\
\hline \multirow{3}{*}{\multicolumn{3}{|c|}{ Model }} & \multirow{2}{*}{$\begin{array}{l}\text { Unstandardized } \\
\text { Coefficients } \\
\end{array}$} & \multirow{3}{*}{$\begin{array}{l}\text { Standardized } \\
\text { Coefficients } \\
\text { Beta } \\
\end{array}$} & \multirow[t]{3}{*}{$\mathrm{t}$} & \multirow[t]{3}{*}{ Sig. } & \multirow{2}{*}{\multicolumn{2}{|c|}{ Collinearity Statistics }} \\
\hline & & & & & & & & \\
\hline & & & Std. Error & & & & Tolerance & VIF \\
\hline \multirow{3}{*}{1} & (Constant) & 7.713 & 4.962 & & 1.555 & 0.138 & & \\
\hline & Enterprise risk management & .491 & .301 & .367 & 1.629 & 0.122 & 1.000 & 1.000 \\
\hline & (Constant) & 4.833 & 4.467 & & 1.082 & 0.295 & & \\
\hline \multirow[t]{4}{*}{2} & Enterprise risk management & .172 & .291 & .128 & .589 & 0.056 & 0.812 & 1.231 \\
\hline & Innovation & .496 & .196 & .552 & 2.535 & 0.022 & 0.812 & 1.231 \\
\hline & (Constant) & -4.749 & 18.676 & & -0.254 & 0.080 & & \\
\hline & Enterprise risk management & .792 & 1.211 & .593 & 0.655 & 0.052 & 0.049 & 2.311 \\
\hline \multirow[t]{3}{*}{3} & Innovation & 1.013 & .997 & 1.127 & 1.016 & 0.033 & 0.033 & 3.466 \\
\hline & $\begin{array}{l}\text { Interaction term between ent } \\
\text { management and Innovation }\end{array}$ & terprise risk -0.033 & 0.063 & -0.888 & -0.529 & 0.046 & 0.014 & 6.771 \\
\hline & Dependent Variable: Organiza & tional performance & & & & & & \\
\hline
\end{tabular}

Source: Research findings 2017.

Table 1 shows the test results for $\mathbf{H a}$ and from the model summary it shows that $\mathrm{R}^{2}=0.394$ the Adjusted $\mathrm{R}^{2}=$ $0.273, \mathrm{~F}=3.254, \mathrm{p}$-value $=0.0460$., $\mathrm{DW}=2.507$. This result shows the interacting term innovation on the effect of the relationship between ERMS and performance can only be explained by $39.4 \%$ of the factors of the study. Adjusted $\mathrm{R}^{2}$ indicates that $27.3 \%$ of ERMS affects performance. The DW of 2.507 shows the absence of autocorrelation since a DW value between 1.5 and 3 is acceptable. From the ANOVA table the results show model 1 with a significance p-value of 0.122 and F of 2.654. Model 2 shows a p-value of 0.021 with F value of 4.904 while model 3 shows a p-value of 0.050 with F value of 3.254 . This can be concluded that the model is generally acceptable.

However, from the Coefficients table it shows Beta of -0.888 which indicates that for every $1 \%$ change in ERMS there is change of -0.888 in performance. The p-value is given as 0.0460 which indicates rejection for the Null Hypothesis and VIF of 6.771 which shows collinearity is within the acceptable level of between 1 and 10 . The conclusion is that Christian-based hospitality businesses in Kenya have considerably adopted some aspects of innovation in their business processes and as an interacting term, it does influence the relationship between ERMS and performance of the organizations.

\section{Discussion}

Various ERMS were adopted by the Christian hospitality businesses. In responses to effects of integrated management systems various levels of achievement were noted. Integrated management systems must come from internal initiatives to connect all processes to operate as one with appropriate connectivity and linkages that remove barriers. There must be linkages between the inner circle management and the peripheral management. Christian hospitality businesses with the Church clergy must have seamless obstacles that promote understanding of the business aspects and the spiritual aspects so that such integration may foster quality services and achievement of objectives.

It has been shown in this study that various integrated approaches have been adopted by Christian hospitality businesses in managing their risks. In hypothesis testing, a p-value of equal to or less than 0.05 was adopted. Hypothesis Ha was to measure the relationship between ERMS and performance with innovation acting as a moderating variable. The Hypothesis was accepted with a p-value of 0.046 and $F$ value of 3.254. It can be seen that the $\mathrm{F}$ value was high that is above 1.

Innovation seemed fairly strong in the model, especially Model 1 with a p-value of 0.021 . It can be concluded that the innovation adopted by Christian hospitality sector in Kenya has a positive moderating effect on the relationship between ERMS and performance. The organizations are therefore to maintain this in order to improve on their performance. From a conceptual perspective, it has been shown that innovation is promoted by ERMS and vice versa. 
From the studies made by Crimson and Villar-Lopez (2014) in Spanish firms showed that innovation in technology of production and other systems leads to better performance, but only where integrated management approach is used to moderate risks, a position also supported by Barathy and McShane (2014). Thorburn and Langdale (2003) propose that incremental innovation should be directed towards achieving quality products and services. In their study of the moderating effect of the technology adopted by the industry on the relationship between corporate governance and entrepreneurship showed the technology indeed moderated this relationship. These studies support the findings of this study that innovation is a key in influencing the relationship between ERMS and performance. This however requires financial investment in such innovation, an action that is likely to hamper small businesses in achieving higher performance. The study showed that most of the Christian hospitality business fall under the category of SME's using number of employees as a determinant of size of business. This is a challenge that Christian hospitality sector may have to deal with and may be consider expansion to take advantage of economies of scale. In this context, the sector needs to understand what are the drivers and inhibitors of innovation so that they can reinforce the drivers and suppress the inhibitors. As Naqshbandi and Singh (2014) in their study of managerial ties that support or stifle innovation, the sector in enhancing innovation, need to develop ties with professional organizations that will provide the necessary innovation that may influence the relationship between Enterprise Risk Management and performance. Already Damanpour (1991) has suggested that there are certain organizational factors that may enhance the effectiveness of innovation which are formalization and standardization of work and the scope of the innovation adopted. Combined with effective ERMS such innovations would significantly influence performance of the sector.

\section{Conclusion}

From the discussions of the findings it has been established that innovation has a moderating effect on the relationship between ERMS and performance of the Christian hospitality businesses in Kenya. Innovation has shown to be the most active interacting term in the joint effect of ERMS and innovation on performance. It can also be concluded that a more integrated approach in enterprise risk management strategies and innovation must be adopted by the Christian-based hospitality businesses in order for them to impact performance because positive performance should be the end result of ERMS where stakeholder value is enhanced. Various ERMS were adopted by the Christian Hospitality Businesses. For example: social integration has been achieved through effective communication and teamwork. In responses to effects of integrated management systems various levels of achievement were noted. Integrated management systems must come from internal initiatives to connect all processes to operate as one with appropriate connectivity and linkages that remove barriers. There must be linkages between the inner circle management and the peripheral management. Christian hospitality business with the clergy must have seamless obstacles that promote understanding of the business aspects and the spiritual aspects so that such integration may foster quality services and achievement of objectives. From the information processing theory point of view it can be concluded that Christian hospitality sector should be structured in such a manner that information flow can be facilitated for purposes of eliminating confusion and doubt (Faribank, Labianca, Steensma \& Meters, 2006). The study shows that CBHB have shown some success in adoption of innovation, but must guard against any possible administrative malfunctioning either through BOD inefficiencies, or skills discrepancies that may have a negative effect on performance.

Hypothesis (Ha) sought to establish whether there was a significant moderating effect by innovation on the relationship between enterprise risk management strategies and organizational performance of Christian-based hospitality businesses in Kenya. The findings shows that innovation as an interacting term between ERMS and performance is significant in their relationship because the significance level $\mathrm{p}=0.033$ is within the acceptable range of 0.05 and below. Innovation therefore needs to be encouraged for the Christian hospitality sector to continue improving their performance while at the same time implementing the most effective ERMS for value addition.

The main purpose for ERMS is to reduce duplication that may escalate costs and hence improve on organizational value. Removal of relationships and responsibilities that conflict and thereby eliminating power struggles, should be the aims of CBHB in Kenya. Through this Christian hospitality sector can be able to recognize and or eliminate unnecessary informal systems such as cultural groupings, doctrinal biased leanings and other interest groups that may operate against the organizational drive to succeed. However, such integration must take cognizance of the availability of the resources such as skilled personnel with sufficient experience, financial resources and other physical resources needed to drive change. The results on skills development shows that Christian hospitality sector has exhibited its commitment to supporting training and develop or acquire the necessary skills from the market place and this is a positive step these organizations have taken. 
Innovation is expected to change the direction of operation or action in order to bring about positive change that may lead to reduction in costs, increased savings and return on investment (Frankelius, 2009). Innovation can now easily be accessed because of easy knowledge diffusion. Christian hospitality sector therefore can easily adopt available innovations for doing their businesses astechnologies, staff skills, effective BOD and customer satisfaction which are likely to add value.

The results of the study showed that a majority of the Christian hospitality businesses fall under the SME's category. It has been established that innovation adaptation depends on the ability to finance the innovation (Thorburn \& Langdale, 2003). SME's may not have sufficient capacity to quickly implement an innovation as would a large organization. Organizational gap or lag especially as a result of absence of innovation adaptation caused by organizational incongruities (Kaplan 1994) such as administrative malfunctioning can lead to impaired performance. The study shows that Christian hospitality sector has shown some success in adoption of innovation despite their size, but must guard against any possible administrative malfunctioning either through BOD inefficiencies, or skills discrepancies that may stifle innovation that may lead to a negative effect on performance.

As a moderator in the causal relationship between ERMS and performance it has shown its effectiveness. From a theoretical perspective, systems innovation is interactive and therefore provides feedback between market orientation and technological adaptation that impacts performance. The causal relationship between ERMS and performance brought about in this study therefore confirms this theoretical perspective.

\section{References}

Banks, E. (2004). Alternative risk transfer: Integrated risk management through insurance, reinsurance and capital markets. John Wiley \& Sons Ltd. West Sussex.

Barney, J. B., Wright, M., \& Ketchen Jr., D. J. (2001). The resource-based view of the firm: Ten years after 1991. Journal of Management, 27(6), 625-641.

Barret, D. J. (2006). Leadership Communication. New York, NY McGraw-Hill.

Camison, C., \& Villar-Lopez, A. (2014). Organizational innovation as an enabler of technological capabilities and firm performance. Journal of Business Research, 67(1), 2891-2902.

Carton, R. B., \& Hofer, C. W. (2006). Measuring organizational performance: Metrics for entrepreneurship and strategic management research cheltenham, U.K., Northampton, MA: Edward Elgar.

Combs, J. G., Crook, T. R., \& Shook, C. L., (2005). The dimension of organizational performance and its implications for strategic management research. Research Methodology in Strategy and Management, 259-286.

Copeland, T. E, Weston J. F., \& Shastri, K. (2005). Financial theory and corporate policy (4th ed.). Pearson Addison Wesley N.Y.

COSO. (2011). Enterprise risk management - Integrated framework.

Damanpour, F. (1991). Organizational Innovation: A Meta-Analysis of the effects of determinants and moderators. Academy of Management Journal, 34(3), 555-590.

Das, T. K., \& Teng, B., (2001). Trust control and risk in strategic alliances: An integrated framework. Organizations Studies, 22(2), 251-283.

Drury, C. (2000). Management and cost accounting (5th ed.). London, UK: Thomson Learning.

Fairbank, J. F., Labianca, G. J., Steensma, H. K., \& Meters, R. (2006). Information processing design choices, strategy and risk management performance. Journal of Management Information Systems, 23(1), 293-319.

Frankelius, P. (2009). Questioning two myths in innovation literature. Journal of High Technology Management Research, 20(1), 40-51.

Georges, D. (2013). Risk management and critic. Risk Management and Insurance Review, 16(2), 147-166.

Gibbs, K. L. (2007). Accounting management and control. John Murrey (Publisher) Ltd London.

Government of Kenya (GoK), (2007). Report on Evaluation of the Performance of Public Agencies - Nairobi. Government Printer.

Henry, J., \& Mayle, D. (2002). Managing innovation and change (2nd ed.). Open University Business School \& Sage Publications. London - Thousand - New Delhi. 
Hoyt, R. E., \& Liebenberg, A. P. (2011). Determinants of enterprise risk management: Evidence from appointment of chief risk officers. Insurance Review, 6, 37-52.

Hurley, R. F., \& Hult, G. T. M. (1998). Innovation, market orientation and organizational learning: An integrated and empirical examination. Journal of Marketing, 62(3), 42-54.

ISO 3100. (2015). Certified internal Control Risk Analyst.

Johnson, G., Scholes, K., \& Whittington, R. (2008). Exploring corporate strategy (8th ed.). Prentice Hall N.Y.

Kaplan, R. S., \& Norton, D. P. (1992). The balanced scorecard - Measures that drive performance. Harvard Business Review, 70(1), 71-79.

Kaur, S., Naqshbandi, M. M., \& Jayasingam, S. (2014). Open innovation: Drivers and inhibitors. Asia-Pacific Tech Monitor, 31(2), 20-25.

Kersnar, J. (2009). "Winning Signs": Why risk management is letting down companies and what to do about it. C.F.O Europe magazine, 2, 25-30.

Klein, R. W. (2013). Insurance market regulations, catastrophe risk, competition and systemic risk. Handbook of Insurance ( $2^{\text {nd }}$ ed.). Springer, NY.

Koelling, M., Neyer, A. K., \& Moeslein, K. M. (2010). "Strategies towards innovative services: findings from the German service landscape. Service Industries Journal, 30(4), 609-20.

Krause, V., \& Lehner, O. M. (2012). The nexus of enterprise risk management: Systematic literature review. ACRN Journal of finance and risk perspective, 1(1), 91-163.

Laursen, A., \& Salter, A. (2006). Open for innovation: The role of openness in explaining innovation performance among U.K. manufacturing firms. Strategic Management Journal, 27(2), 131-150.

Liebenberg, A., \& Hoyt, R. (2003). Determinants of enterprise risk management: Evidence from appointment of chief risk officers. Risk Management and Insurance Review, 6(1), 37-52.

Mckinley, W., \& Scherer, A. G. (2000). Some unanticipated consequences of organizational restructuring. Academy of Management Review, 25(4), 735-752.

McShane, M. K., Nair, A., \& Rustambeckkov, E. (2011) Rating of emotional risk management strategies and their degree of implementation Journal of Accounting and Finance, 26(4), 641-65.

Miles, S. (2012). Stakeholders: Essentially contested or just confused? Journal of Business Ethics, 108(3), $285-298$

Naqshbandi, M. M., \& Singh, S. K. G. (2014). Do managerial ties support or stifle innovation? Industrial Management \& Data Systems, 114(4).

Nocco, B. W., \& Stultz, R. M. (2006). Enterprise risk management: Theory and practice. Journal of Applied Corporate Finance, 18(4), 8-20.

O'Connor, P., \& Murphy, J. (2004). Research on information technology in the hospitality industry. International Journal of Hospitality Management, 23(5), 473-484.

Olavsrud. T. (2015). How risk management leads to increased profit margins. Digital magazine.

Orlando, C. R. (2000). Racial diversity, business strategy and organizational performance: Resource- based view. The Academic of Management Journal, 43(2), 164-177.

Perry-Smith, J. E., \& Mannucci, P. V. (2017). From creativity to innovation: The social network drivers of the four phases of the idea journey. Academy of Management Review, (42) 53-79.

Ping, T. A., \& Muthuveloo, R. (2015). Impact of ERM on firm performance: Evidence from Malaysia. Asian Social Science, 11(22), 149.

Rogers, E. M. (2003). Diffusion of innovation (5th ed.). New York: Free Press.

Rogers, E. M., Medina, U. E., Rivera, M. A., \& Wiley, C. J. (2005). Complex adaptive systems and the diffusion of innovation. The Public sector Innovation Journal, 10(3).

Salge, T. O., Farchi, T., Barret, M. I., \& Dposon, S. (2013). When does openness really matter? A contingency study of health-care innovation projects. Product Innovation Management, 30(4), 659-676.

Santomero, A. M., \& Babbel, D. F. (1997). Financial risk management by insurers. Journal of Risk and Insurance, 64(2), 231-270. 
Tahir, I. M., \& Rizali, A. R. (2011). The relationship between enterprise risk management and firm value: Evidence from Malaysian public listed companies. International Journal of Economics and Management Sciences, 1(2), 1079-1110.

Thompson, A. A., Strickland, A. J., \& Gamble, J. E. (2008). Crafting and executing strategy. Text, reading and cases. London: McGraw Hill.

Thorburn, L., \& Langdale, J. (2003). Embracing change: Case studies on how Australian firms use incremental innovation to support growth. Australian Science. Technology and Engineering Council Reports.

Tsai, W. (2001). Knowledge transfer in intraorganizational networks: Effect of network position and absorptive capacity on business unit innovation and performance.

Vasile, E., Ion, C., \& Mitran, D., (2012). Risk management in financial activity. Internal Auditing \& Risk Management, 7(25).

Verhees, F. J. M., \& Muelenberg, T. J. (2004). Market orientation, innovativeness, product innovation and performance in small firms. Journal of Small Business Management, 42(2), 134-154.

Warren, K. (2008). Strategic management dynamics. London Business School. John Wiley \& Sons Ltd..

Wessel, M., \& Christensen, C. M. (2012). Managing the risk of disruptive innovation. Harvard Review.

White, D. W., \& Simas, C. F. (2008). An empirical investigation of the link between market orientation and Church performance. International Journal of Voluntary Sector Marketing, 13, 153-165.

Yegon, C. K., Gekara, J. M., \& Wanjau, K. (2014). Effects of firm size on enterprise risk management of listed firms in Kenya. Journal of Business and Management, 16(5), 86-95.

Zahra, S. A. (1996). Governance, ownership and corporate entrepreneurship: The moderating impact of industry technology. Academy of Management Journal, 39(6), 1713-1735.

\section{Copyrights}

Copyright for this article is retained by the author(s), with first publication rights granted to the journal.

This is an open-access article distributed under the terms and conditions of the Creative Commons Attribution license (http://creativecommons.org/licenses/by/4.0/). 